\author{
(online) $=$ ISSN $2285-3642$ \\ ISSN-L = $2285-3642$ \\ Journal of Economic Development, Environment and People \\ Volume 10, Issue 4, 2021 \\ URL: http://jedep.spiruharet.ro \\ e-mail: office jedep@spiruharet.ro
}

\title{
Marketing mix strategy determinants and social media in veterinary- based business: experience from Serbia
}

\author{
Milena Ilić P. ${ }^{1]}$, Milica Gojković ${ }^{2}$, Ksenija Blažić ${ }^{3}$, Karla Radi Ciuperca $^{4}$ and \\ Violeta-Elena Simion \\ ${ }^{1}$ University Business Academy in Novi Sad, Faculty of Contemporary Arts, Belgrade, Serbia; Information \\ Technology School ITS - Belgrade, Belgrade, Serbia, \\ ${ }^{2}$ NCR Corporation Belgrade, Serbia, \\ ${ }^{3}$ Syneos Health Belgrade, Serbia, \\ ${ }^{4}$ VetCenter Otopeni, Romania \\ ${ }^{5}$ Faculty of Veterinary Medicine, Spiru Haret UniversityBucharest, Romania;
}

\begin{abstract}
The paper is dedicated to testing the entrepreneurial idea of founding a service micro company in the field of veterinary medicine - Animal Care. The starting point is the theoretical aspect of marketing mix services observed through the prism of a specific company in the field of agribusiness. For the needs of the research, secondary sources were used and a survey was conducted which gave the results of the influence of the elements of marketing mix services on marketing communication towards the users of the company Animal Care. It was determined that the effects of promotion, especially in the field of digital marketing, directly affect the increase in sales of products and services, and thus the satisfaction of consumers \& users in veterinary services. The results of the research provided answers to research questions and helped the entrepreneur to understand that selected elements of the marketing mix help in the promotion of products and services of Animal Care companies. Respondents showed interest in using the services of the Animal Care company with the help of the Animal Care android application and website as a selected distribution channel, but also for the promotion of new services and offers of the company.
\end{abstract}

Keywords: Marketing mix services, social media, digital marketing, veterinary service, consumer satisfaction

JEL Codes: L26, M31, Q13

How to cite: Ilic, M., Gojković, M., Blažić, K., Radi Ciuperca, K., \& Simion, V. (2021). MARKETING MIX STRATEGY DETERMINANTS AND SOCIAL MEDIA IN VETERINARY-BASED BUSINESS: EXPERIENCE FROM SERBIA. Journal of Economic Development, Environment and People, 10(4). doi:http://dx.doi.org/10.26458/jedep.v10i4.712

Corresponding author. Tel.: + 381605522581

E-mail address: milena.ilic@its.edu.rs 


\author{
(online) = ISSN $2285-3642$ \\ ISSN-L = $2285-3642$ \\ Journal of Economic Development, Environment and People \\ Volume 10, Issue 4, 2021 \\ URL: http://jedep.spiruharet.ro \\ e-mail: office jedep@spiruharet.ro
}

\title{
1. Introduction
}

Marketing activities in the companies of the Republic of Serbia have significantly increased compared to the last decades of the 20th century, but their level is still unsatisfactory (Stanković \& Popović, 2018). Certain differences in development and implementation have been observed in companies depending on the industry they cover, but also by the company's size, international business, type of ownership (Mitic, 2015). Namely, it is noticed that the development of brand applications and innovations in marketing is becoming more and more significant. Although recognized as a strategic tool in business, marketing in Serbia is often accused of neglecting the needs of consumers and putting the interests of traders first (Vukajlović \& Ćurčić, 2016). To operate more successfully, however, the focus is on researching the importance of factors that make up the competitiveness of the company, marketing being one of them, certainly. Marketing mix and its instruments are the subjects of research in numerous studies (Stankov et al., 2016), (Božić et al., 2016) and (Filipović, 2019).

In Serbia, veterinary marketing is more recent. It is believed that the lack of a marketing plan and activities in veterinary practice may be a consequence of not understanding the need to promote products and services intended for animals, but also their placement on an increasingly complex market. In the meantime, marketing in the field of veterinary medicine has started to be applied as in other branches of industry, primarily due to the emergence of competition but also adaptation to the needs of target customer groups (Vidić, 2012).

Various factors lead to success in the company's business, but thanks to the implementation of marketing strategy, new customers can be attracted in such a way that both functional and emotional satisfaction is connected with the purchase of products, so the point of differentiation overcomes competition (Kotamena et al., 2020). (Novitasari et al., 2021).

According to Radnović et al., successful marketing strategy management requires service providers to solicit accurate, reliable, and timely feedback from customers (Radnović et al., 2015). Marketing strategy offers different visions through which a company achieves its mission, vision, and goals. This was also supported by the researcher Dodor (2015), who emphasized the support for the application of marketing tools as key to the success and maintenance of marketing strategy with the mandatory application of marketing mix elements that are especially valuable for the agro-industry, which includes veterinary medicine.

Marketing experts believed that the marketing mix should be improved in the late 1970s. This resulted in the development of an extended marketing mix theory by Booms\&Bitner in 1981, which added three new elements to the fundamental $4 \mathrm{P}$ principle (product, price, distribution channels, and promotion) (Kotler, Armstrong, 2017). This allowed for the inclusion of product elements that are services in the extended marketing mix, without the product itself being viewed as a mere material object. The extended version of the 7Ps consists of the following components (Kotler, Keller, 2016): In the service sector, the marketing mix, or the 7Ps, consists of the following: product, price, location, promotion, people, processes, and physical evidence (Subotić, et al, 2021). 


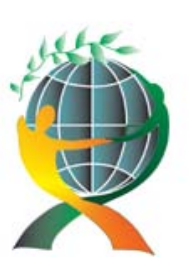

\author{
(online) $=$ ISSN $2285-3642$ \\ ISSN-L = $2285-3642$ \\ Journal of Economic Development, Environment and People \\ Volume 10, Issue 4, 2021 \\ URL: http://jedep.spiruharet.ro \\ e-mail: office jedep@spiruharet.ro
}

Although the 7Ps have been in effect since the 1980s, they continue to be widely studied due to their fundamental logic, which remains valid in today's marketing environment and is reflected in marketing's ability to adapt marketing mix concepts. While there are many different ways of communicating these days, some of them, such as social media, are more effective than others in terms of boosting sales (Ilić et al, 2021).

An important part of marketing strategy is social media. The veterinary industry has been updating and improving constantly. Besides the technology of the medical devices special developed for the veterinary industry, now we have the client and practice management software and the possibility to advertise the practice to a large range of customers.

A part of the marketing strategy is social media platforms. Facebook, the most popular platform is present as a business page and also as a personal profile for more and more veterinary clinics and hospitals. First-quarter of 2021 Facebook registered 2,85 billion active users. Facebook is the biggest social network worldwide.

The world of social media marketing is extremely volatile. New platforms frequently emerge, and the existing ones keep introducing unique features. Instagram is more popular among millennials and Gen Z, with more than $63 \%$ of Instagram users 18 to 34 years of age. According to a 2018 survey, Instagram users spent an average of 53 minutes per day online using the platform. Instagram is known for its stunning and visually engaging content. The third place is Twitter. Statista.com says Twitter is particularly popular in the US where in April 2021 had reached 73,2 million users. Japan and India were ranked second and third with 54.15 and 18.8 million users. The statistical website states that Facebook was used by $82.32 \%$ of the population in Europe, in June 2021. Second place is Twitter, Pinterest is third, followed by Instagram and Youtube. (Gs.statcounter.com, 2021). Twitter is the go-to social media platform for checking out the latest industry trends and breaking news. The next platform for business trends and updates is Linkedln that I consider more oriented to professional networking. You can use Linkedln to get the attention of top-level executives to get a better job or to sell them your products and services. In our opinion, Tik Tok is in fifth position. Tik Tok's popularity has remarkably increased. While it's often perceived as a social media platform for the younger generation, the Tik Tok users base has been steadily growing in age too. The share of Tik-Tok 25-to-34 years old Tik Tok users rose from $22.4 \%$ to $27.4 \%$ between January to April 2021. The best option for video content is YouTube. Since its launch in 2005, YouTube has become synonymous with online video. In 2019 a staggering 93\% of Internet users watched online videos at least once a month. And while Facebook narrowly bested YouTube in total active users last year, YouTube remains the most active social platform, with people watching more than a billion hours of videos every day - that's more than they watched Netflix and Facebook videos combined, according to Panopro web site (Panopro, 2021).

\title{
2. Entrepreneurial idea
}

This project involves testing the business idea of starting an agency or entrepreneurial venture in the form of micro-enterprises or entrepreneurs within the activities related to the care of pets or the provision of various services. The services that would be offered are diverse: pet walking, pet sitting, pet care, pet grooming, services of a veterinarian ... in short, everything that the owner cannot do himself during the day. The project would be implemented in four phases: 


\author{
(online) = ISSN $2285-3642$ \\ ISSN-L = 2285 - 3642 \\ Journal of Economic Development, Environment and People \\ Volume 10, Issue 4, 2021 \\ URL: http://jedep.spiruharet.ro \\ e-mail: office jedep@spiruharet.ro
}

- drawing up a plan and activities;

- implementation;

- prototype (several days of testing the whole service), initial promotion, and

- further promotion/advertising and official market entry.

The clear (SMART) goals of this entrepreneurial project are:

- to complete implementation of the project within six months from the beginning;

- business expansion within a year by double (increase in the number of users by two to four times after each quarter and a reciprocal increase in the number of employees after each quarter);

- to increase profits by at least two to four times after each quarter;

- to provide additional locations (1-2) for pet sitting in relation to the increase in work within a year;

- to increase in salaries of employees within eighteen months by about $15 \%$ (if revenues are higher than expected, the increase may occur earlier);

- business expansion first to the entire municipality of Čukarica after the first six months of operation, and then in eighteen months to the entire Belgrade area;

- branch office in two more big cities (Novi Sad and Nis) in three years;

- branches in several other larger cities as well as in the surrounding towns of Belgrade, Novi Sad, and $\mathrm{Nis}$ in five years, and

- any subsequent possibility of increasing the work in six or more years from the beginning of work.

Nowadays, life is very fast. People want to have pets, but due to too many obligations, it happens that they give up or neglect them. This service is intended primarily, although not exclusively, for people who would like to have pets, and know that they cannot give them enough attention, and for people who already have pets, but are aware that they can rarely take proper care of them.

It is for the above reasons that the Animal Care team provides daily care to all pets because they deserve it. This is exactly the mission of this organization. The vision of Animal Care is that every pet has everything necessary for a hedonistic lifestyle.

\title{
3. Survey of business idea, testing the idea and application functionality
}

During the analysis, it was determined that Android phones are mostly used in Serbia so that particular platform was chosen for that reason. It is planned that after the first year of business, an iOS application will be designed and developed. The website is designed to help the user access the application. It should be the link between an internet search for such a service and an application. There is a contact phone number and email of the organization on the page. The primary goal is to use it to connect the user to the application. Although there are possibilities for users to find the application by looking at the android store, it is clear that at least $70 \%$ of such services are searched "surfing" the Internet.

To make it easier for the organization to get acquainted with the environment and to get feedback from future users, an online survey was organized and conducted. It is important to note that the survey 


\author{
(online) $=$ ISSN $2285-3642$ \\ ISSN-L = $2285-3642$ \\ Journal of Economic Development, Environment and People \\ Volume 10, Issue 4, 2021 \\ URL: http://jedep.spiruharet.ro \\ e-mail: office jedep@spiruharet.ro
}

aims to have a rough idea of the expetations of start-up users in order to prepare the organisation for entering the market and to be able to project their income statement.

\title{
3.1. Methodological organization of research
}

The survey was conducted using the Google Forms tool and was conducted by sharing a link to potential users and advertising oral communication. As a tool for analysing the results, Microsoft Excel was used with the accompanying functions it contains, as well as Google Forms itself. The importance of researching customer attitudes is important both in theory and in the practice of marketing activities, which can significantly anticipate trends in consumer behaviour (Đelošević et al., 2017). Fluctuations in consumer behaviour are constant and occur under the influence of their own or others' experience, but also family, work colleagues, friends, etc. The research of the relationship between attitudes, intended and actual consumer behaviour starts from the fact that buying behaviour is primarily influenced by previously established consumer habits, but also intentions, which are determined based on previous experiences (Stanković et al., 2019).

Since the research work focuses on the impact of the elements of the marketing mix on the effectiveness of marketing communication when it comes to the promotion of veterinary products and services of Animal Care, the research problem could be formulated through the following questions:

1. Do the elements of marketing mix services help the company Animal Care in the realization of the promotion of its products and services, but also of other factors?

2. To what extent did the analysis of the marketing mix services of the above-mentioned company indicate the special importance of the digital marketing application?

3. How much did the display of marketing mix services reflected the interest of the potential target group for the Animal Care application?

The survey consists of three sections of questions, and there are 22 questions in total. It is designed to contain short and clear questions, not to create animosity for the respondents, and not to take much time. The questions mostly ask the users to express their satisfaction with grades 1-5 (grade 1 represents "absolutely disagree", and grade 5 "absolutely agree"). Furthermore, there are several questions where respondents have to choose one of the offered answers, as well as several questions where they can choose more answers if they want. There are also two open-ended questions. A five-point Likert scale with offered answers was used for most questions: Absolutely disagree; Do not agree; Neither agree nor disagree; Agree; and Absolutely agree.

The survey was completed by 48 respondents. Data can be essential for future business. The three sections into which the survey is divided are socio-demographic issues; questions about the business idea, i.e., Animal Care, and Application-related questions. 


\author{
(online) = ISSN $2285-3642$ \\ ISSN-L = $2285-3642$ \\ Journal of Economic Development, Environment and People \\ Volume 10, Issue 4, 2021 \\ URL: http://jedep.spiruharet.ro \\ e-mail: office jedep@spiruharet.ro
}

Before each section, a small text is entered which aims to explain the section and bring the offer closer to the user so that the user is informed about what is expected of him so that the offer is understandable and brings more positive comments and future cooperation.

\title{
3.2. Survey results
}

The section in general looks at social issues that are important when determining market segments and choosing the company's most valuable customers. To find out whether the respondent is male or female, the initial question revolves around gender. Surprisingly, the survey was completed by 24 women and 24 men. In the second question, the researchers wanted to know how old the respondents were. The results indicate that most of the respondents are young people, while a variety of ages are present. It's expected that the greatest number of pet owners belong to the age group of 18-25 years, as this is when students and recent graduates have the freest time, and so they are the most likely to own pets. The age group of 26-33 years comes in second place in a percentage of $20.8 \%$. Age group $42-49$ is in third place, with $16.7 \%$ of the votes, and age group $50-57$ is in second place, with $16.67 \%$ of the votes. Younger generations are less visible.

According to respondents, there are three educational categories: high school, college, and those with the highest level of education. The largest number of respondents ( $50 \%$ of all graduates from high schools and faculties, followed by $31.3 \%$ of all graduates with the title of doctor or master) belong to the group of respondents who finished high school and graduated. Those who graduated from high school totaled $18.8 \%$ of the population. The majority of respondents, $72.9 \%$ stated that they have a pet, while the remaining $27.1 \%$ of respondents said they do not. The largest percentage of respondents, $39.6 \%$, own one pet. $33.3 \%$ of all the pet owners in the U.S. have 2 or more pets (simply put, 16 out of 48 respondents have more than one pet). When it comes to Animal Care, this can be advantageous to the organization. Out of $85.4 \%$ of respondents, $85.4 \%$ had never used a similar service, while $14.6 \%$ had previously used one.

Distribution Channel: On a readiness-to-use basis, nearly four out of five people reported that they would use services offered by Animal Care, and the value of this data for the organization is very high because it shows that a large number of people are interested in using services offered by Animal Care. The large majority of respondents, 30 of them (62.5\%), agreed that Bele Vode requires this organization, which is important for future business. Moreover, respondents had an opinion on the possibility of new services being developed and the additional property being built, with 38 of them (79.2\%) having a positive response. A list of services was presented to respondents to obtain an overview of what services are in demand in the market. To be expected, the service of dog sitting and walking garnered the most votes and was responsible for all the other results and percentages are shown in the following chart.

PRICE: Respondents were asked their opinion on the adequacy of their prices. To calculate the average satisfaction of the respondents, the mean value was used. overall, participants in the survey indicated that they were very satisfied with the prices, with an average score of 4.5. of the 7 people who answered, 6 said that the prices were fine (there were no answers 1 and 2 ). 


\author{
(online) = ISSN $2285-3642$ \\ ISSN-L = $2285-3642$ \\ Journal of Economic Development, Environment and People \\ Volume 10, Issue 4, 2021 \\ URL: http://jedep.spiruharet.ro \\ e-mail: office jedep@spiruharet.ro
}

When I'm not bringing my pet along on vacation, I intend to use the pet-friendly services my company provides. Selecting respondents who travel a lot made the results possible, which allowed for market segmentation and sample selection. This time, the answers were just as positive as many as 37 out of 48 respondents (or 77.1 percent) offered a grade of 5, which translates to 77.1 percent agreement.

This organization wants to find out how many people have faith in the services it offers. The answers are acceptable, as only 16 people rated their answers as 2 or 3 on a scale of 1 to $5.66 .7 \%$ of the others provided grades of 4 or 5 .

A DISTRIBUTION CHANNEL: In a question where respondents were asked to select how they would schedule the desired service, the first of the options selected is singled out. The following chart illustrates the results. The rest of the questions had to do with whether users think the application's functionality is essential and whether they think it reduces the workload associated with reservations. Over 30 respondents gave an average of 5 on all of these questions. The last question in the survey asks "Are you planning on using the Animal Care organization's services in the future?" The following chart displays the results. At the end of the survey, we asked the respondents if they would use the services of this organization if they did not have pets, for example, if they would adopt or buy pets. Of the nine respondents, all gave positive answers, and two were ambiguous. If this organization started doing business, the number of potential users would increase.

We may observe that AnimalCare 2 is in a strong positive correlation with confidence variabile. The stronger the confidence in confidence in the people who offer these services, and the user knew it before the most intense frequency in using AnimalCare services when going on holidays. We also may observe a moderate positive correlation between Price, Holiday and Animal Care_future. Once the client is familiar with the Animal Care offer, he intends to use the Animal Care services in the future, if the price is reasonable. Also, a moderate positive correlation is manifested between App_simplifies and App_simplicity App_functionality. The application simplifies the use of the service due to the appropriate functionality of the app. The design and functionality (simplicity) of the application is also important for the clients and simplify and increase the use of these services (Table- correlation matrix)

The sample used in this analysis contains 48 records. It was exploratory research given the entrepreneurship idea was tested.

$\mathrm{H} 1$ : When people were going on holiday they would use the Animal care service, but it depends on confidence level, previous positive experience and it is used mainly for dogsitting.

To prove the $\mathrm{HI}$ hypothesis, we designed a regression model

Overall, the regression model is representative ( $R 2$ is 0.721 ). The variation of the independent variable (confidence, AnimalCare_futur, dogsitting) explains $72 \%$ of the variation of the dependent variable (Animal-Care). The other percentages should be explained by other variables such as application, price, etc.

The ANOVA test confirms the before mentioned findings because $F>F$ crit and Sig $F<0.01$ (Table below). The T-test marginal significance level for estimated coefficients is less than only 0.01 for the cereals' coefficient, meaning that this coefficient is very well estimated, and the others could be better estimated. Following the statistical test F, the resulting coefficient for confidence, AnimalCare_futur, 


\author{
(online) $=$ ISSN $2285-3642$ \\ ISSN-L = $2285-3642$ \\ Journal of Economic Development, Environment and People \\ Volume 10, Issue 4, 2021 \\ URL: http://jedep.spiruharet.ro \\ e-mail: office jedep@spiruharet.ro
}

dogsitting variables are $0,18,0,31$ and 0,39 , with a probability of guaranteeing results (Prob) of 0.01 (less than the sensitivity threshold of 0.05 ) so these variables' coefficients are well estimated. (Table at appendix).

The equation of the regression model is presented below:

Total land organic farming $=2,31+0,18 \times$ Confidence $+0.31 \times$ AnimalCare_future $+0,39 \times$ Dogsitting

Thus, our hypothesis is grounded by statistical analysis - regression model.

Table 1. Correlation matrix (see the appendix)

Table 2. Regresion significance and coeficients.

\title{
SUMMARY OUTPUT
}

Regression Statistics

$\begin{array}{lr}\text { Multiple R } & 0,721332 \\ \text { R Square } & 0,520319 \\ \text { Adjusted R } & 0,488341 \\ \text { Square } & \\ \text { Standard Error } & 0,492724 \\ \text { Observations } & 49\end{array}$

ANOVA

\begin{tabular}{lccccr} 
& df & SS & \multicolumn{2}{c}{ MS } & \multicolumn{2}{c}{ S Significance F } \\
Regression & 3 & 11,85054 & 3,950179 & 16,2708 & $2,65 \mathrm{E}-07$ \\
Residual & 45 & 10,92497 & 0,242777 & & \\
Total & & 48 & 22,77551 & &
\end{tabular}

CoefficientsStandard Error t Stat

Intercept

2,319389

0,361038

P-value

Lower $95 \%$

Upper $95 \%$

confidence

Animal

0,182408

0,075964

6,42423

$7,31 \mathrm{E}-08$

1,592222

0,029409

3,046556

0,316

0,09358

3,376772

0,020532

0,127519

0,335407

Car_future

0,398263

0,185957

2,141693

0,001521

0,023726

0,50448

Dogsitting

\section{Discussion}

From the answers enclosed, it is clear that the future of this organization can be bright, but what goes in favour of entering the market are the answers to the question of whether you would use such services. It 


\author{
(online) $=$ ISSN $2285-3642$ \\ ISSN-L = 2285-3642 \\ Journal of Economic Development, Environment and People \\ Volume 10, Issue 4, 2021 \\ URL: http://jedep.spiruharet.ro \\ e-mail: office jedep@spiruharet.ro
}

can be seen that as many as 37 out of 48 respondents think that they would use such services, which is more than satisfactory (last question). As can be seen in the percentages, high satisfaction is expressed that such an organization exists, i.e., will exist from the moment the business starts and it is reflected in the number of $62.5 \%$.

When all the answers and user satisfaction in percentages are summed up, the positivity towards Animal Care is noticeable. The almost imperceptible number of answers to some questions was negative, and also a small number of users abstained - most of the answers were positive, and even rated the highest score of 5 , which represents the maximum agreement on a question.

\title{
5. Conclusion
}

The goal that the organization Animal care wants to achieve, and is related to its application and website, is that the application should represent a connection with the user and simplify the scheduling of the service. In particular, the focus is on bookings of several days, hours, or more bookings in one month. By using the application as a type of reservation, every appointment is saved, remembered and there are reminders for it, so both parties will be sure of what they offer, or what they require.

All these elements should emphasize the desire for the existence of such an organization as it is considered necessary in recent times, and this was proved by a survey where the answers to the questions in every sense were more than positive and which prove that the hypotheses, desires and the goals of the organization are achievable and that if it is established, both parties (users and Animal Care) can benefit. The survey also clearly proved that the organization should enter the market without fear, test its limits, work on promotion and advertising, constantly strive for the better, and, of course, try to do its part honestly and in the best possible way. The answers, which were often maximally positive, put the survey at a high level of validity of all analyses and indicate what the organization should focus on, how to target users, in which direction to develop, and how to make a real competitor in the market and the organization that brings profit and from whose profit one can live while doing the job one loves.

Future research will relate to the design of activities to ensure the growth and development of the described business idea.

\section{References}

[1] Božić, M., Kirin, S., Plazinić, A. (2016). Primena koncepta marketing miksa u organskoj proizvodnji, Ekonomija: teorija i praksa, 4, 55-70.

[2] Đelošević, I., Dević, Ž., \& Spasojević, B. (2017). Predviđaju li stavovi ponašanje potrošača, Ekonomski signali, 12(1), 31-40.

[3] Filipović, J. (2019). Potencijali unapređenja promocije i prodaje sjeničkog sira, Marketing, 50(1), 57-66. 


\author{
(online) = ISSN $2285-3642$ \\ ISSN-L = 2285 - 3642 \\ Journal of Economic Development, Environment and People \\ Volume 10, Issue 4, 2021 \\ URL: http://jedep.spiruharet.ro \\ e-mail: office jedep@spiruharet.ro
}

[4] GS Statcounter web site https://gs.statcounter.com/ (11.08.2021.)

[5] Ilić, M., Subotić, M., Anđelić, S., Ristić, B., \& Popović Šević, N. (2021). Marketing mix service (7P) and destination brand evaluation in rural tourism - a case study of Country Club Zdravkovac in Serbia, 37th IBIMA conference proceedings.

[6] Kohler, C., Haferkamp, J. (2019). Evaluation of delivery cost approximation for attended home deliveries, Transportation Research Procedia, 37, 67-74.

[7] Kotamena, F., Senjaya, P., \& Prasetya, A. B. (2020). A Literature Review: Is Transformational Leadership Elitist and Antidemocratic?. International Journal of Social, Polica and Law, 1(1), 36-43.

[8] Kotler, P. \& Keller, KL (2016). Marketing management. London: Pearson Education.

[9] Kotler, P., \& Armstrong, G. (2017). Principles of Marketing, 17th edition, Global edition, Pearson.

[10] Mitić, S. (2015). External Relationships and Marketing Practices in Serbian Firms: the Intangible Capital Perspective, Economic Annals, LX (204), 75-104.

[11] Novitasari, D., Siswanto, E., PURWANTO, A., \& Fahmi, K. (2021). Authentic Leadership and Innovation: What is the Role of Psychological Capital?, International Journal of Social and Management Studies, 1(1), 1-21.

[12] Panopro web site http://www.panopro.com (11.08.2021.)

[13] Radnović, M., Marić, R., Radnović, V., Ilić, M., \& Lukač, D. (2015). Marketing Research on Passenger Satisfaction with Public Transport Service in the City of Belgrade, Promet - Traffic\&Transportation, Vol. 27, No. 1, 47-57, ISSN: 1848-4069.

[14] Stankov, B., Jovičić, D., \& Marjanski Lazić, S. (2016). Istraživanje zadovoljstva studenata uslugom visokog obrazovanja uz primenu anketnog upitnika, Škola biznisa, 1, 43-61.

[15] Stankov, B., Jovičić, D., \& Marjanski Lazić, S. (2016). Istraživanje zadovoljstva studenata uslugom visokog obrazovanja uz primenu anketnog upitnika, Škola biznisa, 1, 43-61.

[16] Stanković, Lj., \& Popović, A. (2018). Izazovi za razvoj marketinga u zemljama u razvoju, Marketing, 49(1), 3-10.

[17] Stanković, Lj., Đukić, S., \& Stanković, J. (2019). Istraživanje stavova i motiva potrošača prema 'zelenim proizvodima' kao osnova za razvijanje marketing strategija preduzeća u Republici Srbiji, Marketing, 50(3), 167-178.

[18] Subotić, M., Vulić, M., Ristić, B., Popović Šević, N., Šević, A., \& Ilić, M. (2021). Evaluating the impact of 5Cs model factors and marketing mix analysis: A case study. 37th IBIMA conference proceedings

[19] Vidić, V. (2012). Marketing usluga savremene veterinarske prakse, Arhiv veterinarske medicine, vol. 5, br. 2, 67-75.

[20] Vukajlović, Đ., \& Ćurčić, N. (2016). Ocena faktora konkurentnosti i inovativnosti u cilju ostvarivanja tržišnog učešća, Ekonomija: teorija i praksa, 3, 35-54. 


\author{
(online) $=$ ISSN $2285-3642$ \\ ISSN-L = $2285-3642$ \\ Journal of Economic Development, Environment and People \\ Volume 10, Issue 4, 2021 \\ URL: http://jedep.spiruharet.ro \\ e-mail: office jedep@spiruharet.ro
}

\title{
Appendix
}

Table 1. Correlation matrix

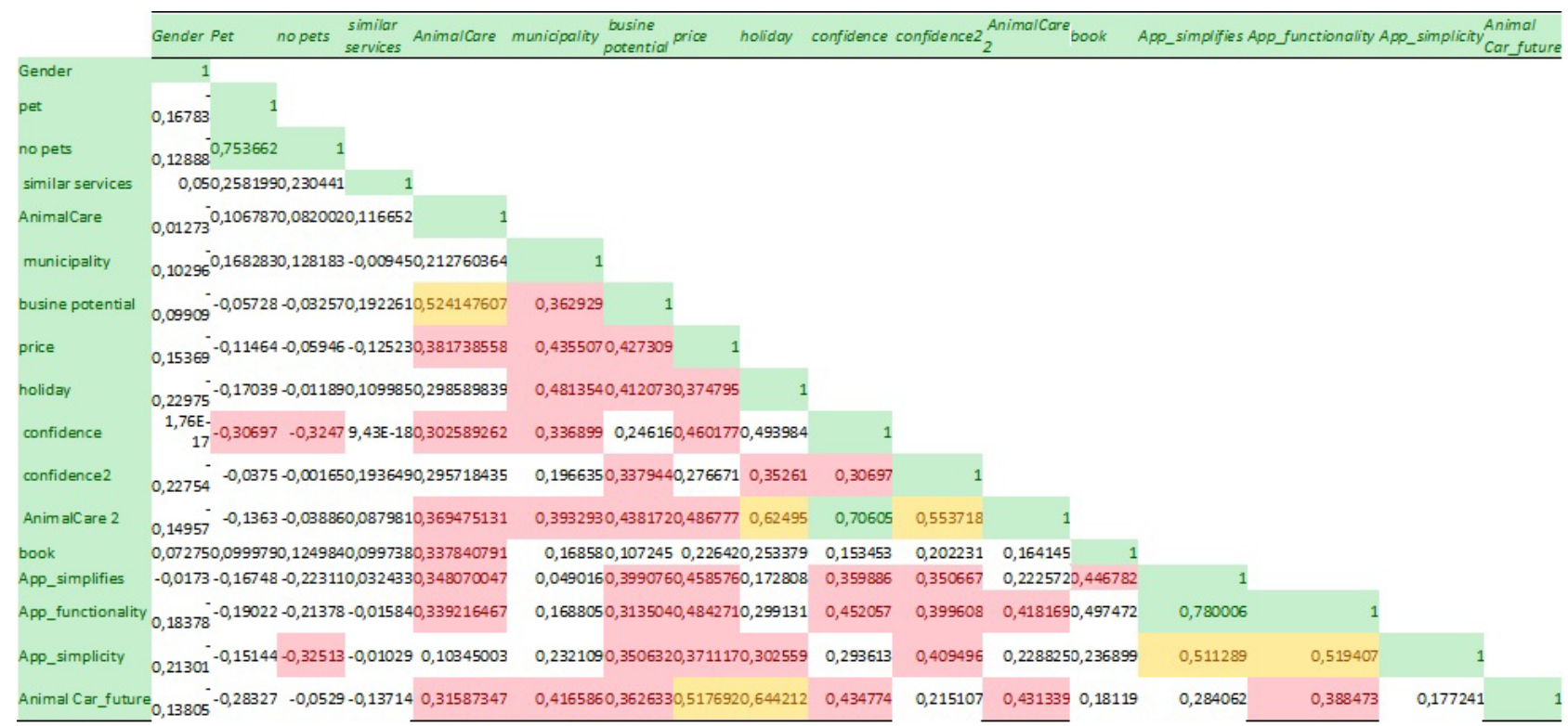

